\title{
Study of sulphate-reducing bacteria corrosion in the weld joint for API X-70 steel $^{(\bullet)}$
}

\author{
J. E. Flores*, C. Patiño-Carachure*, I. Alfonso*, J. A. Rodríguez*** and G. Rosas**
}

\begin{abstract}
The corrosion behavior originated by sulfate-reducing bacteria (SRB) was studied in two regions of welded API X-70 steel pipeline. The studies were focused on base material (BM) and heat affected zone (HAZ), from the internal region of the pipe. SRB were extracted from oil and grown in a Postgate medium. Corrosion was evaluated at $60^{\circ} \mathrm{C}$ for times between 5 and 64 days. Potentiodynamic polarization curves, obtained by electrochemical techniques, indicated surface activation at short times. Structural and morphological characterizations were carried out by scanning electron microscopy $(\mathrm{SEM})$ and optical microscopy $(\mathrm{OM}) . \mathrm{H}_{2} \mathrm{~S}$ concentration and $\mathrm{pH}$ were also measured. Results showed an important increase in the corrosion damage up to 20 days, influenced by the SRB activity, which lead to a maximum of $\mathrm{H}_{2} \mathrm{~S}$ (pH minimum). It was found a localized corrosion attack in the $\mathrm{HAZ}$ in a higher quantity compared to $\mathrm{BM}$; and the formation of a thin film on the steel surface, originated by corrosion products and bacterial activity.
\end{abstract}

\section{Estudio de la corrosión por bacterias sulfato-reductoras en la unión soldada de un acero API X-70}

\begin{abstract}
Resumen
El comportamiento ante la corrosión, originada por bacterias sulfato-reductoras (SRB), fue estudiado en dos regiones de un tubo de acero soldado API X-70. Los estudios se enfocaron en el material base (BM) y la zona afectada térmicamente (HAZ), en la parte interna del tubo. Las SRB fueron extraídas del petróleo y cultivadas en un medio Postgate. El comportamiento a la corrosión fue evaluado a una temperatura de $60^{\circ} \mathrm{C}$, por periodos comprendidos entre 5 y 64 días. El análisis de las curvas de polarización potenciodinámicas, obtenidas por técnicas electroquímicas, indicó la activación de la superficie para tiempos cortos. La superficie fue caracterizada estructural y morfológicamente mediante microscopia electrónica de barrido (SEM), así como mediante microscopía óptica (OM). La concentración de $\mathrm{H}_{2} \mathrm{~S}$ y el $\mathrm{pH}$ también fueron medidos. Los resultados mostraron un aumento importante de la corrosión para tiempos mayores a 20 días, lo cual fue influenciado por la actividad de las SRB, que guía a una concentración de $\mathrm{H}_{2} \mathrm{~S}$ máxima ( $\mathrm{pH}$ mínimo). Se encontró corrosión localizada en la HAZ en mayor cantidad que en el BM, así como la formación de una película delgada sobre la superficie del acero, originada por los productos de corrosión y la actividad bacteriana.
\end{abstract}

Palabras clave Corrosión; API X-70; HAZ; Bacterias-sulfato-reductoras; MIC.

\section{INTRODUCTION}

API X-70 is one of the most used steels for oil industry, usually in pipelines for hydrocarbons transportation, e.g. PEMEX (Petróleos Mexicanos), in the Gulf of Mexico. Corrosion in this steel is considered a serious problem, and the cause of accidents and crashes. This process is accelerated by both environmental action (oil, water or aqueous solutions) and the great variety of microorganisms living in it ${ }^{[1 \text { and } 2]}$. The phenomenon originated due to these microorganisms is known as microbiologicalinduced corrosion $(\mathrm{MIC})^{[3]}$. SRB are in great part the cause of MIC in steel pipelines. These bacteria are anaerobes that require a complete absence of oxygen, and a highly reduced environment to

(•) Trabajo recibido el día 10 de octubre de 2011 y aceptado en su forma final el día 18 de enero de 2012.

* Facultad de Ingeniería, Universidad Autónoma del Carmen, Campus III, Avenida Central S/N, Esq. con Fracc. Mundo Maya, C.P. 24115, Ciudad del Carmen, Campeche, México.

Corresponding author: Dr. Cristobal Patiño Carachure.E-mail: cpatino@pampano.unacar.mx.

** Instituto de Investigaciones Metalúrgicas, Universidad Michoacana de San Nicolás de Hidalgo, Edificio "U”, C.U. Apartado Postal 52-B, CP 58000, Morelia, Michoacán, México.

*** Centro de Investigación en Ingeniería y Ciencias Aplicadas, Universidad Autónoma del Estado de Morelos, Av. Universidad 1001. Col. Chamilpa. C. P. 62209, Cuernavaca, Morelos, México. 
function efficiently. Hydrocarbons supply this medium to SRB and also give them required organic nutrients. For thermophilic SRB species, growth temperature is between 45 and $65^{\circ} \mathrm{C}{ }^{[4]}$, and corrosion products are often $\mathrm{Fe}_{\mathrm{x}} \mathrm{S}_{\mathrm{y}}$, such as troilite, pyrrhotite and mackinawite ${ }^{[5]}$. Some theories have being used in order to explain the influence of microorganisms on the corrosion process. One theory explains how the bacteria employ cathodic hydrogen, through consuming hydrogenases enzyme for sulphate reduction ${ }^{[3]}$. The second theory considers that SRB corrosion is due to the formation of a highly active volatile phosphorous compound, which reacts with bulk iron to form iron phosphate ${ }^{[6]}$. A third theory is attempting to describe the process in terms of putting pressure on other factors, such as iron sulphide formed as cathode, where the bacteria generate the sulphides ${ }^{[3]}$. Some works report that SRB origin localized corrosion, specifically electrochemical corrosion by pitting ${ }^{[7 \text { and } 8]}$. This kind of corrosion is localized in zones with microstructural changes, such as the observed in $\mathrm{HAZ}$, or zones presenting carbide precipitation, intermetallic phase formation, grain size increase or high residual stresses concentration. On the other hand, welds are also preferentially susceptible to corrosion $^{[9]}$. This form of corrosion is the result of galvanic coupling, whereby the weld metal acts as an anode and the pipe material as a cathode ${ }^{[10]}$.

Efforts in order to minimize anaerobic steel MIC include the use of cathodic protection and barrier coatings. Nevertheless the corrosion risk depends on both, the number of organisms and their activity ${ }^{[11]}$. Previous work about the MIC in API X-70 steel reports the effect of $\mathrm{SRB}$ on corrosion ${ }^{[4]}$, however this analysis for the HAZ was not found in literature. Therefore, our first objective is the extraction of SRB from oil samples, and their growth in a Posgate medium. Our second objective is to study the comparative effect of the MIC on both, BM and HAZ, for a welded API X-70 steel pipe, taking into account the effect of the microstructural modifications originated in the steel.

\section{EXPERIMENTAL PROCEDURE}

API X-70 steel weld samples were obtained from PEMEX pipes. Chemical composition, in wt \%, can be observed in table I.

Bacteria were extracted from a crude oil sample, supplied from the Cantarell field, in the Gulf of Mexico, Campeche, Mexico. Bacterial growth media were prepared using distilled water and bacteriological nutrients according to the Handbook of Microbiological Media ${ }^{[12]}$. Postgate bacterial growth medium was selected in order to isolate thermophilic bacteria. This medium is composed of $\mathrm{CaSO}_{4}(1.0 \mathrm{~g}), \mathrm{MgSO}_{4} .7 \mathrm{H}_{2} \mathrm{O}(2.0 \mathrm{~g})$, $\mathrm{NH}_{4} \mathrm{Cl}(1.0 \mathrm{~g}), \mathrm{KH}_{2} \mathrm{PO}_{4}(0.5 \mathrm{~g})$, yeast extract $(1.0 \mathrm{~g})$, ascorbic acid $(0.1 \mathrm{~g})$, thioglycollic acid $(0.1 \mathrm{~g})$, $\mathrm{FeSO}_{4} .7 \mathrm{H}_{2} \mathrm{O}(0.5 \mathrm{~g})$, sodium lactate $(10 \mathrm{ml}$ of $1.0 \mathrm{M}$ solution), sodium pyruvate ( $10 \mathrm{ml}$ of $1 \mathrm{M}$ solution), sodium acetate ( $10 \mathrm{ml}$ of $1 \mathrm{M}$ solution) and $10 \mathrm{ml}$ of Wolfe vitamin solution added to 11 of distilled water. The $\mathrm{pH}$ of the final solution was adjusted to $7.5 \pm 0.2$ using $\mathrm{KOH}(5 \%)$. In order to achieve the growth of the SRB, small amounts of oil were added to the Postgate medium at $60^{\circ} \mathrm{C}$, for times between 5 and 64 days $(5,10,20,32$ and 64 days). These bacteria correspond to the desulfotomaculum genus, and are anaerobic gram-negative bacilli (about $4.2 \mu \mathrm{m}$ ), whose features are: irregular morphology, plane elevation, wavy margin and yellowish pigmentation.

In order to analyze the microstructural changes originated in the HAZ, and its effect on corrosion resistance, only BM and HAZ were exposed at this microbial corrosive medium. For corrosion analysis a three-electrode array glass cell was used, in a Solartron 1280-B Potentiostat-Galvanostat. BM and HAZ samples were used as working electrodes, while a sintered graphite rod was used as auxiliary electrode. Before testing, samples were polished using a 600 grit paper, cleaned with acetone and sterilized in an autoclave at $150^{\circ} \mathrm{C}$ by $20 \mathrm{~min}$, according to ASTM G1-18193 standard. In this work all reported electrochemical potentials are referred to a saturated calomel electrode (SCE). Corrosion potential (Ecorr) was measured and plotted against time. The potential range used was $\pm 0.015 \mathrm{~V}$, referred to Ecorr with a sweeping rate

Table I. Chemical composition (in wt. \%) of the API X-70 steel

Tabla I. Composición química (en \% en peso) del acero API X-70

\begin{tabular}{lcccccccccccccc}
\hline $\mathrm{Fe}$ & $\mathbf{C}$ & $\mathbf{M n}$ & $\mathrm{Si}$ & $\mathbf{P}$ & $\mathbf{S}$ & $\mathrm{Al}$ & $\mathrm{Nb}$ & $\mathrm{Cu}$ & $\mathrm{Cr}$ & $\mathrm{Ni}$ & $\mathbf{V}$ & $\mathrm{Ti}$ & $\mathrm{Ca}$ & $\mathrm{B}$ \\
\hline Balance & 0.031 & 1.48 & 0.13 & 0.012 & 0.002 & 0.033 & 0.10 & 0.29 & 0.27 & 0.16 & 0.004 & 0.012 & 0.0011 & 0.0003
\end{tabular}


of $1 \mathrm{mVs}^{-1}$. Potentiodynamic polarization curves were recorded at $1 \mathrm{mVs}^{-1}$, from $-0.05 \mathrm{~V}$ cathodic potential to $0.75 \mathrm{~V}$ anodic potential, which is of interest for our work. In order to investigate the surfaces and the effect of the corrosion on the microstructures for BM and HAZ, a Nikon Epiphot 300 OM and a JEOL JSM 6400 SEM were used.

\section{RESULTS AND DISCUSSION}

The morphology of BM and HAZ (starting materials) are depicted in figures $1 \mathrm{a}$ ) and $\mathrm{b}$ ). As can be observed, the structures are different for these regions: polygonal ferrite grains and perlite distributed at grain boundaries for BM (Fig. 1 a)), and mainly acicular ferrite in the HAZ (Fig. 1 b)).

These are typical morphologies for these steels series, and it has been reported that have different corrosion resistances according to the environment ${ }^{[13}$ and 14$]$. This microstructural modification in the HAZ could significantly modify the corrosion resistance compared to BM, and will be further analyzed.

Figure 2 shows $\mathrm{H}_{2} \mathrm{~S}$ concentration and $\mathrm{pH}$ evolution, for the Posgate medium inoculated with SRB, at different incubation times. $\mathrm{H}_{2} \mathrm{~S}$ concentration significantly increases from 0 to 20 days, reaching a maximum and decreasing for longer times.

The $\mathrm{pH}$ values present an inversely proportional relation with the $\mathrm{H}_{2} \mathrm{~S}$ concentration. When the concentration of $\mathrm{H}_{2} \mathrm{~S}$ produced by SRB increases, the $\mathrm{pH}$ of the culture medium decreases. This indicates that the medium tends to be more acid, reaching a minimum for 20 days of exposure. These results could be related with the microbial behavior during the incubation time, with growth periods, after which microorganisms stops their multiplication. Therefore, the activity of SRB decreased after 20 days, achieving less acid values due to the $\mathrm{H}_{2} \mathrm{~S}$ diminution.

The variation of the corrosion potential (Ecorr) for different times is illustrated in figure 3, for X-70 steel samples (HAZ and BM) immersed in the Postgate medium, inoculated with SRB.

Important differences can be observed between their values. BM analysis indicates a significant activation during the first 5 days of immersion (from -683 to $-568 \mathrm{mV}$ ). For the HAZ, this activation was from -740 to $-691 \mathrm{mV}$. After 10 days the modification of Ecorr was also more significant for BM. For longer times corrosion potential tends to stabilize, with short changes for both BM and HAZ. These results could be explained due to that at the beginning of the test the surface of the steel is active, while for longer times this surface is covered with corrosion products and a biofilm (film produced by metabolic activities of SRB), stabilizing Ecorr values. The difference between the results for BM and HAZ could be related with both, microstructural modifications and the different effect of the microbial SRB activity on the corrosion process. Acicular ferrite exhibit a high dislocation density, and fine, highly

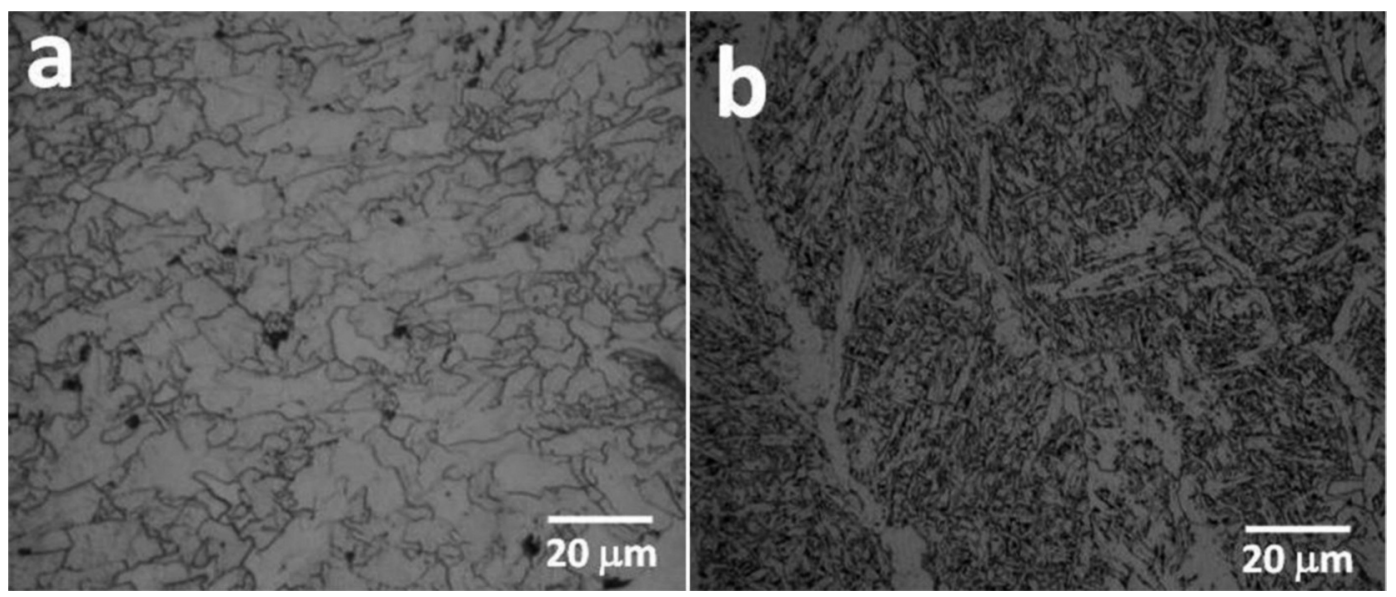

Figure 1. OM images of the microstructure of the API X-70 steel samples for a) BM composed by polygonal ferrite and intergranular perlite and b) HAZ composed by acicular ferrite.

Figura 1. Imágenes por OM de la microestructura de muestras del acero API X-70 para a) BM compuesto por ferrita poligonal y perlita intergranular y b) HAZ compuesta por ferrita acicular. 


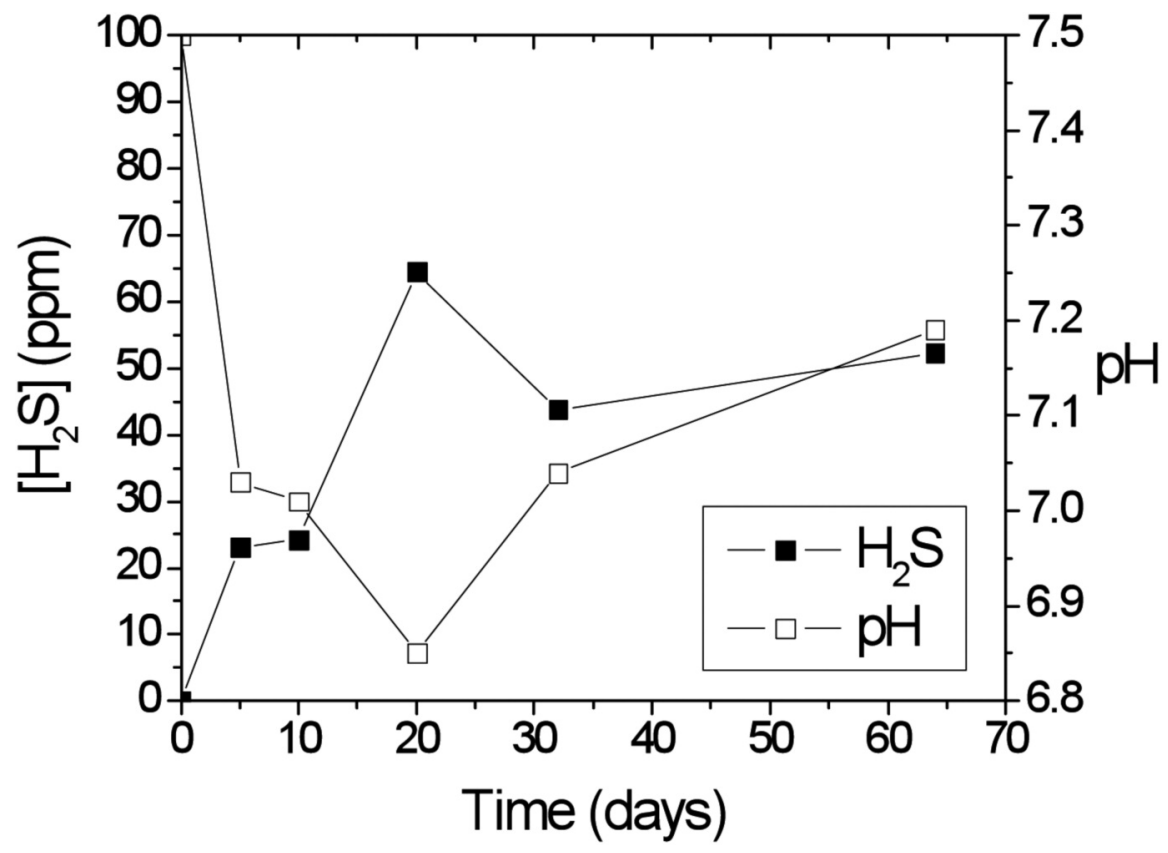

Figure 2. $\mathrm{H}_{2} \mathrm{~S}$ concentration and $\mathrm{pH}$ values, for different incubation times in the Posgate medium + BSR. An opposite relation between both measurements can be observed.

Figura 2. Valores de concentración de $\mathrm{H}_{2} \mathrm{~S}$ y pH para diferentes tiempos de incubación, en el medio Postgate + BSR. Se puede observar una relación inversa entre ambas mediciones.

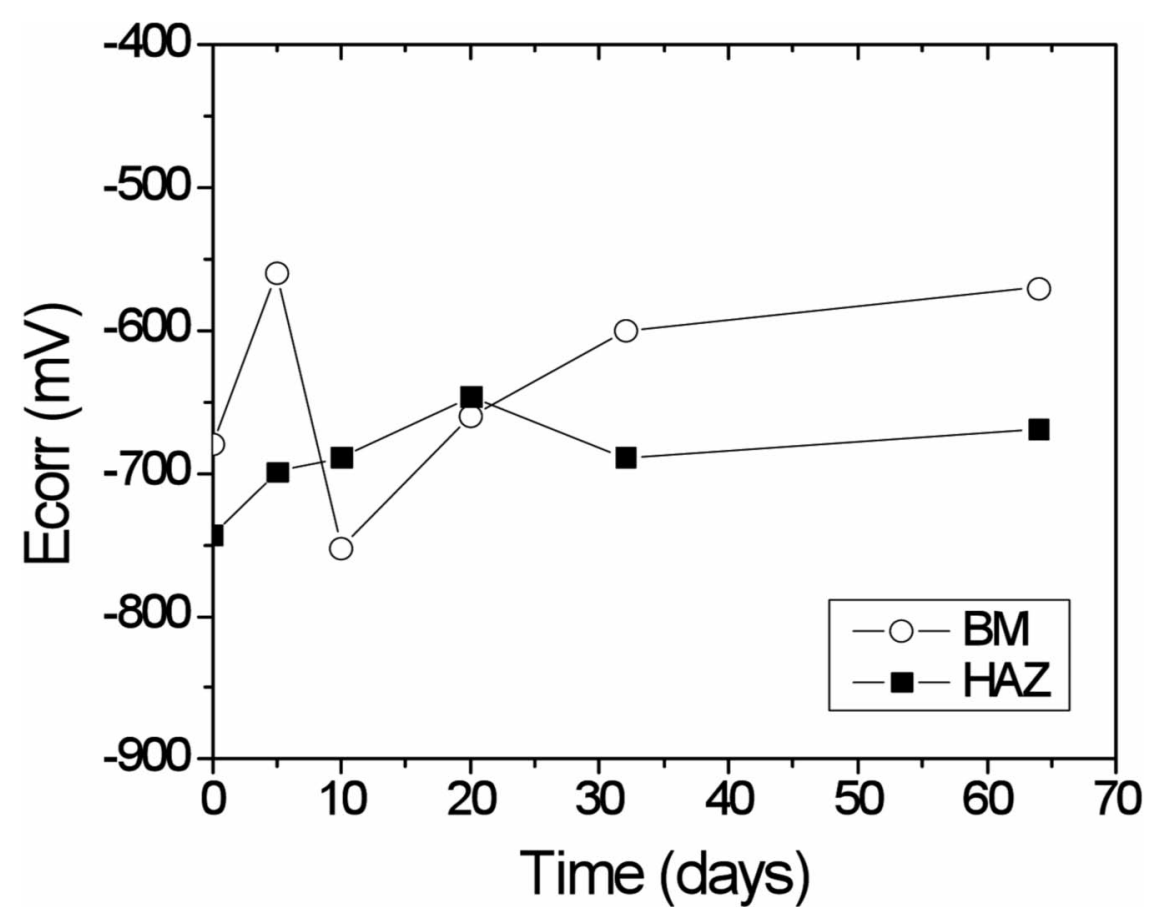

Figure 3. Corrosion potential (Ecorr) behavior for different exposure times, for BM and HAZ. A stabilization of Ecorr at long times can be observed.

Figura 3. Comportamiento del potencial de corrosión (Ecorr) para diferentes tiempos de exposición, para el BM y la HAZ. Se puede observar una estabilización de Ecorr para tiempos largos. 
elongated grains, not exhibited in polygonal ferrite. Acicular ferrite provides good toughness and tensile strength to the welds, because it possesses a fine size and has a higher resistance to the crack propagation. Corrosion tendency of acicular ferrite in welds is greater than other microstructures, but its corrosion velocity can vary. The corrosion resistance of welded metal with acicular ferrite increases with the increasing of acicular ferrite fraction, but too much acicular ferrite leads to accelerate corrosion of welds ${ }^{[15]}$. These results show the importance of our analysis.

Figure 4 shows representative potentiodynamic polarization curves for $\mathrm{BM}$ and $\mathrm{HAZ}$, immersed in the Postgate + SRB medium (exposure times of 20 and 64 days).

At the beginning of the test, the anodic branches have a behavior corresponding to activation or a charge transfer process, attributed to the fact that the microbial activity does not appear yet, and the surface of the steel is covered with corrosion products. After 20 days, anodic branches show characteristics of passivity for both, HAZ and $\mathrm{BM}$ specimens, behavior originated due to the formation of the biofilm on the steel surface. The passive region was found to be wider for BM (184 mV; $112 \mathrm{mV}$ for HAZ). This passivity was not found for BM at 64 days, while for the HAZ at 64 days a small passivity region was observed $(42 \mathrm{mV})$. The noblest potential was obtained for $\mathrm{BM}$ at 64 days $(-565 \mathrm{mV})$. For 64 days transpassive zone potential moved to lower values compared to the obtained at 20 days, while current moved to higher values. These results suggest that HAZ is more sensible to a corrosion attack.

Figures $5 \mathrm{a}$ ) and b) show SEM micrographs for HAZ surface, after 32 days of exposure in the Postgate growth medium with SRB.

The steel surface is not visible, because it is covered by small particles $(1-5 \mu \mathrm{m})$, as can be observed in figure $5 \mathrm{a}$ ). These particles form a film, reported as a mixture of biofilm and corrosion products $^{[7]}$. In figure $5 \mathrm{~b}$ ) the biological part of the film (biofilm) is depicted, composed by kidney-shaped sessile SRB cells, demonstrating the colonization of the metal surface. This film could modify the solutionmetal interface, and affect the interactions between metal surface and the environment, provoking the

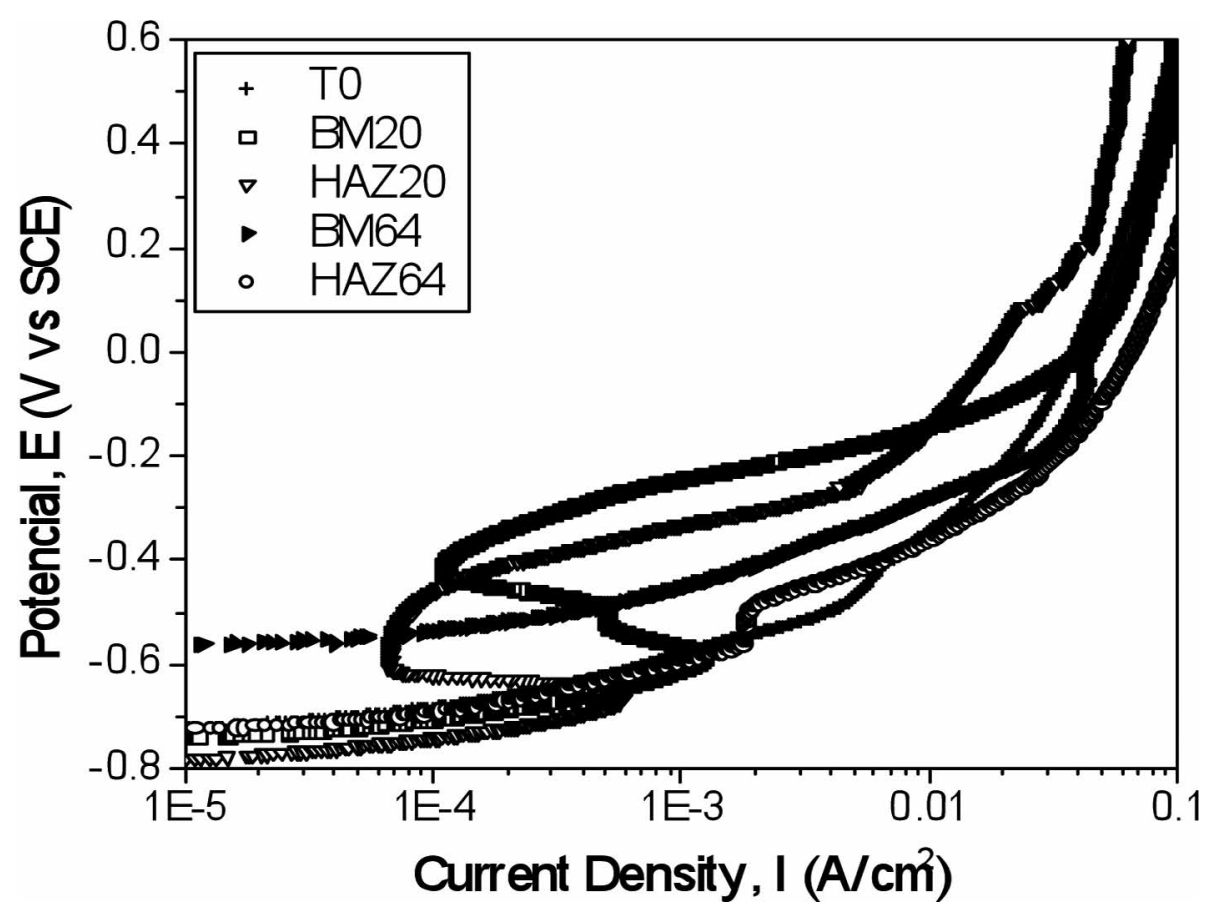

Figure 4. Potentiodynamic polarization curves. T0 corresponds to the beginning of the test; BM20 and HAZ20 to 20 days of exposure for BM and HAZ, respectively; BM64 and HAZ64 represent the behavior for 64 days.

Figura 4. Curvas de polarización potenciodinámicas. T0 corresponde a la prueba de control; BM20 y HAZ20 corresponden a 20 días de exposición para el BM y la HAZ, respectivamente; BM64 y HAZ64 representan el comportamiento para 64 días. 


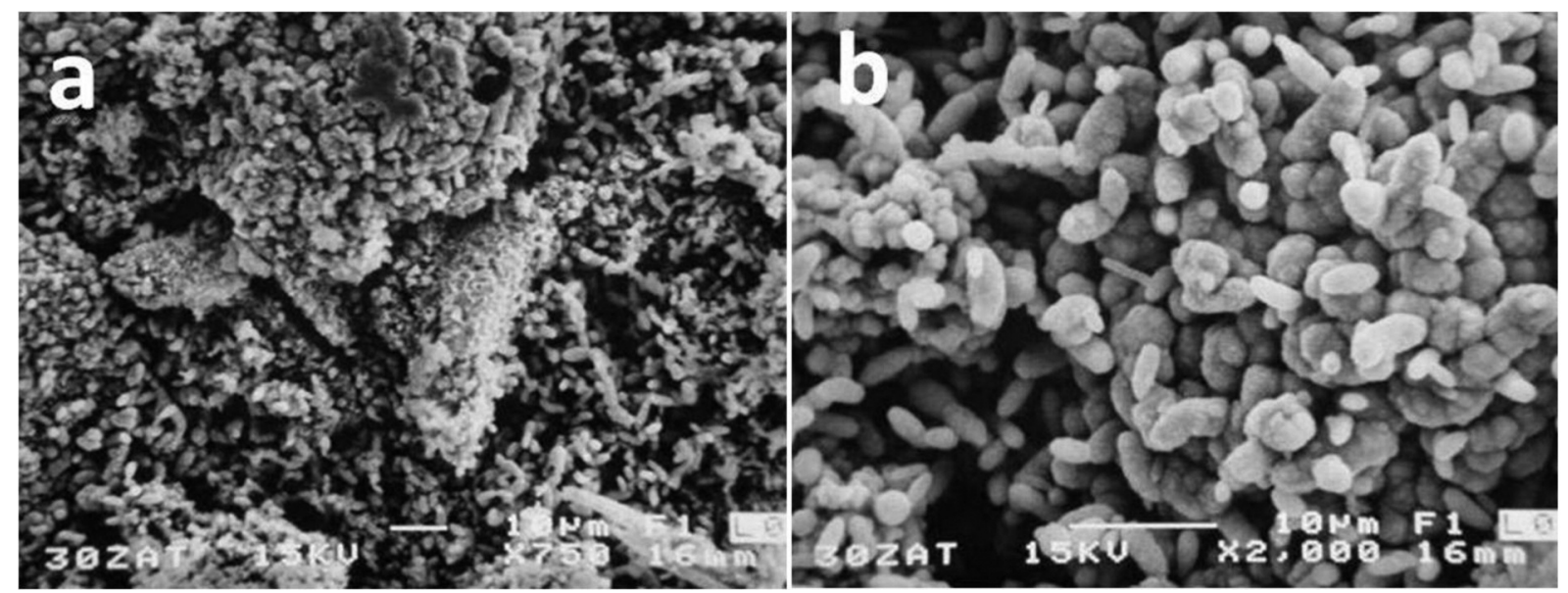

Figure 5. SEM micrographs of the HAZ surface after 32 days of exposure, a) mixture film, composed by a biofilm and corrosion products and b) kidney-shaped SRB cells are clearly observed.

Figura 5. Micrografías de SEM tomadas en la superficie de la HAZ después de 32 días de exposición, a) película compuesta por una bio-película y productos de corrosión y b) células de SRB en forma de riñón claramente visibles.

biodegradation of the metal surface. The biofilm was also observable for BM.

In order to analyze the steel corrosion under the film, the morphology of cleaned steel surfaces (without the film) was studied using OM, and is depicted in figures 6 a) - d).
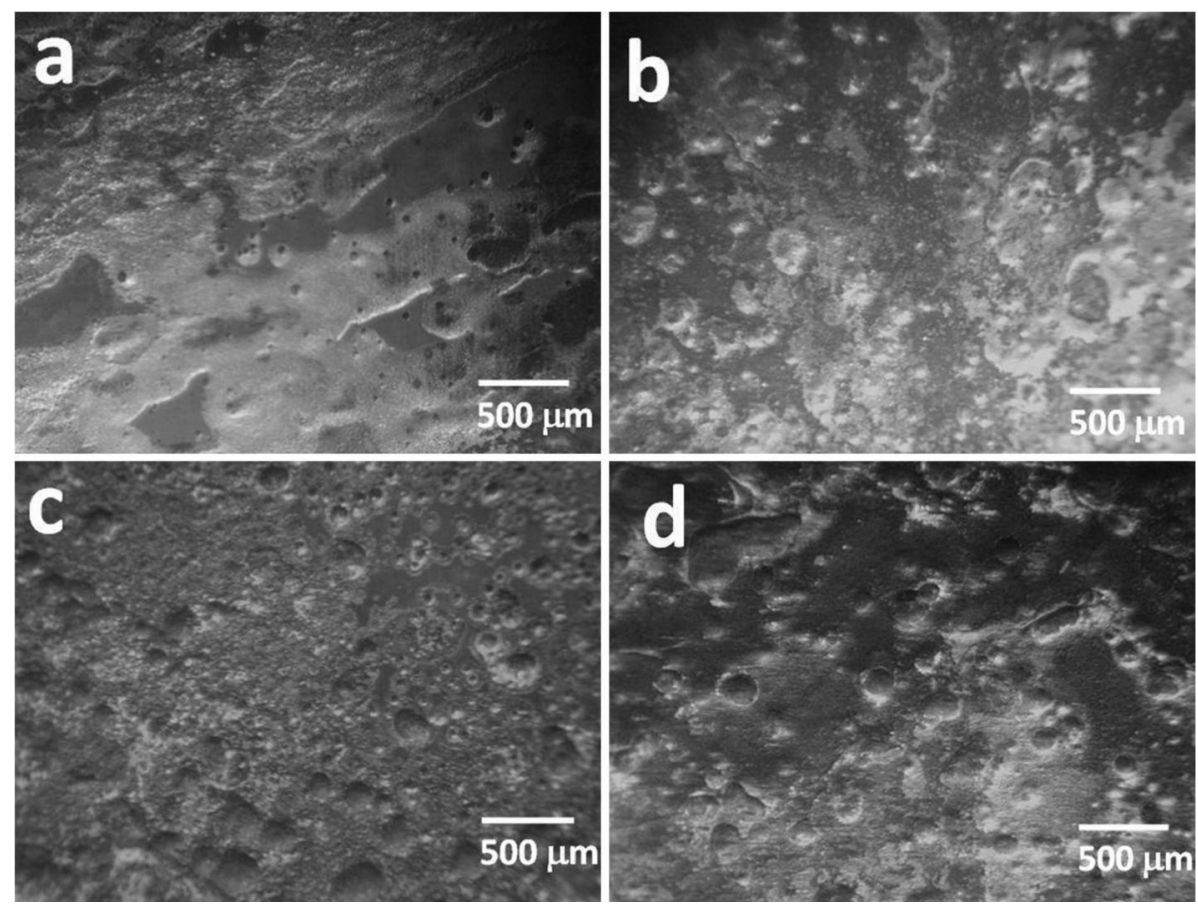

Figure 6. OM micrographs of pitting for: a) BM, 5 days; b) HAZ, 5 days; c) BM, 64 days and d) HAZ, 64 days. Samples for long exposure times show the most aggressive attacks by pitting.

Figura 6. Micrografías de picaduras obtenidas por OM para: a) BM a 5 días, b) HAZ a 5 días, c) BM a 64 días y d) HAZ a 64 días. Las muestras para tiempos largos de exposición presentan un ataque por picaduras más agresivo. 
STUDY OF SULPHATE-REDUCING BACTERIA CORROSION IN THE WELD JOINT FOR API X-70 STEEL ESTUDIO DE LA CORROSIÓN POR BACTERIAS SULFATO-REDUCTORAS EN LA UNIÓN SOLDADA DE UN ACERO API X-70

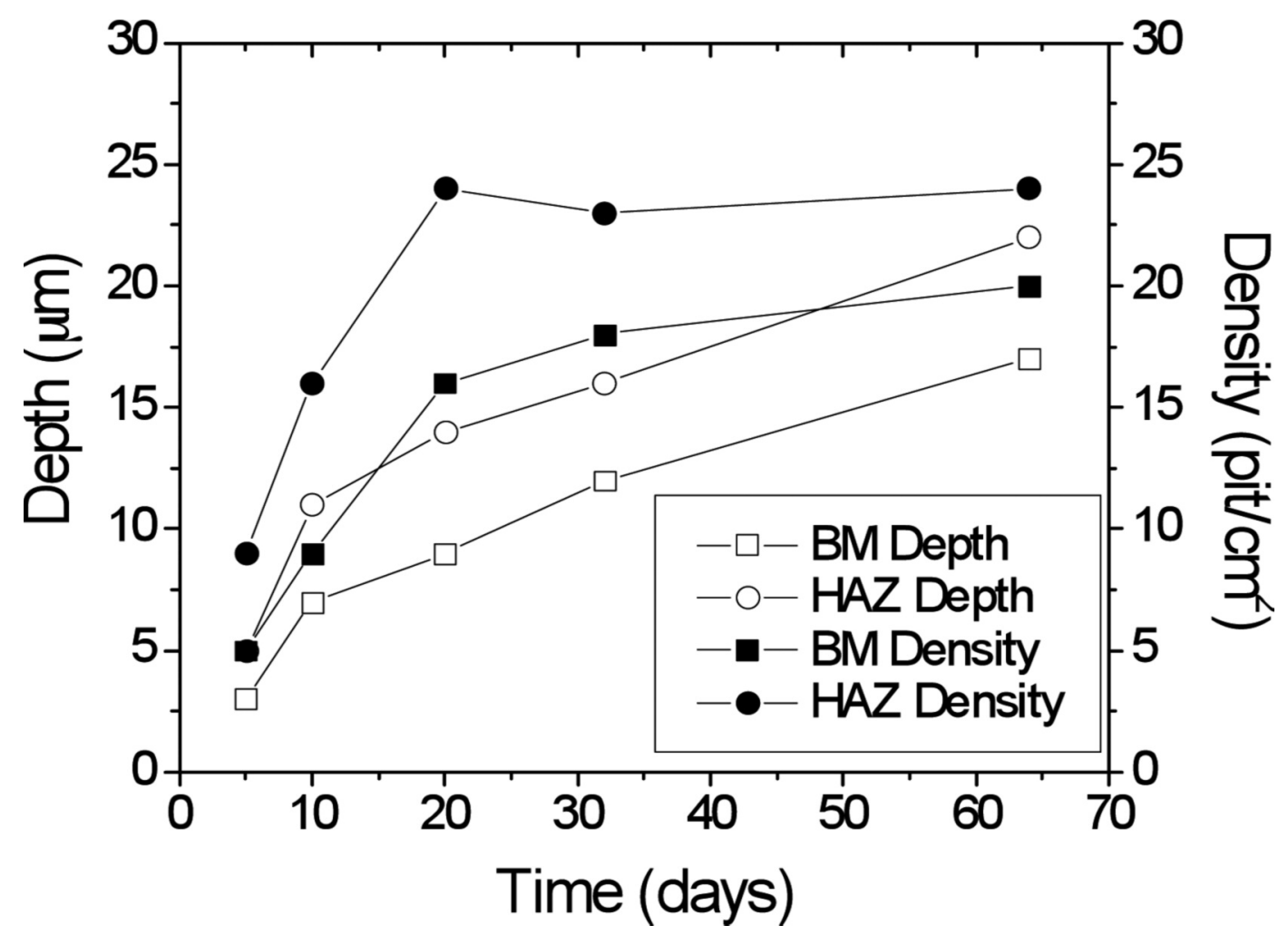

Figure 7. Depth and density of pitting originated on the API X-70 steel, for different exposure times. Samples for the HAZ and longer exposure times present the most aggressive attacks by pitting.

Figura 7. Profundidad y densidad de picaduras originadas sobre el acero API X-70, para diferentes tiempos de exposición. Las muestras de la HAZ y tiempos de exposición largos presentan ataques más agresivos por picaduras.

Localized pitting corrosion is observed for exposure times as short as 5 days for both BM (Fig. 6 a)) and HAZ (Fig. 6 b)). The analysis of the sample exposed 64 days, revealed an important increase in the pitting corrosion compared with the observed for 5 days (Fig. 6 c) for BM and Fig. 6 d) for HAZ). Statistical measurements were carried out in order to analyze the comparative pitting size and density. Pitting size characteristics can be observed in figure 7 .

For BM pitting size increases from 3 for 5 days, to $17 \mu \mathrm{m}$ for 64 days, while for HAZ increases from 5 to $22 \mu \mathrm{m}$. Pitting density shows an important increase too. As can be deduced, pitting attack was more severe for HAZ, fact that could be explained due to the different microstructure of the HAZ, more sensible to this corrosion type. Results also demonstrate the effect of the SRB on the steel corrosion. Cellular activity within the biofilm provides anodic and cathodic regions on the metal surface, promoting electrons flow and originating pitting. Extracellular polymeric substances (EPS), originated by the action of the SRB, can generate physicochemical changes which modify metalsolution interface. These changes are: ions type and concentration, $\mathrm{pH}$ and REDOX potential, and could modify the active or passive behavior of the metal substrate and its corrosion products ${ }^{[7]}$. In order to minimize corrosion problems care must be taken due to microstructural modifications in the HAZ, which is more sensible to corrosion.

\section{CONCLUSIONS}

The effect of sulfate-reducing bacteria in the corrosion of base material and heat affected zone of welded API X-70 steel was studied. From the analysis of the results, the following conclusions can be drawn:

- When the concentration of $\mathrm{H}_{2} \mathrm{~S}$ produced by SRB increased, the $\mathrm{pH}$ of the culture medium decreased. $\mathrm{pH}$ reached a minimum at 20 days, increasing for longer times. 
- Exposed steel surfaces were covered with a film, mixture of corrosion products and kidney-shaped SRB cells.

- The analysis of the corrosion potential showed the surfaces activation at short times. After 20 days corrosion potential tends to stabilize, with short changes for both BM and HAZ. Thus, the presence of the corrosion film could be the cause of this behavior.

- Potentiodynamic polarization curves showed a wider passive region for BM at 20 days of exposure. For longer exposure times a tendency to a displacement to lower potential values and higher currents was found. HAZ was found to be more sensible to corrosion by SRB.

- The analysis of the exposed surfaces showed the presence of localized corrosion, specifically pitting. A higher quantity of pitting was observed for HAZ, related to the difference in microstructures (acicular ferrite for the HAZ, compared to polygonal ferrite and perlite for BM).

\section{REFERENCES}

[1] R. P. George, D. Marshall and R. C. Newman, Corros. Sci. 45 (2003) 1999-2015.

[2] J. Luo and I. Vance, Proc. "Corrosion", Houston TX, NACE, paper 265, 1994, pp. 2-4.

[3] R. Javaherdashti, Anti-Corros. Method M. 46 (1999) 173-180.
[4] R. Torres-Sánchez, J. García-Vargas, A. Alfonso-Alonso and L. Martínez-Gómez, Mater. Corros. 52 (2001) 614-618.

[5] A. K. Lee, M. G. Buehler and D. K. Newman, Corros. Sci. 48 (2006) 165-178.

[6] D. H. Pope, Proc. "Corrosion", Houston. TX, NACE, paper 265, 2000, pp. 2-4.

[7] M. Rodríguez-Hernández, R. GalvánMartínez, R. Orozco-Cruz, E. A. Martínez and R. Torres-Sánchez, Mater. Corros. 60 (2009) 982-986.

[8] J. W. Costerton, G. G. Geesey and P. A. Jones., Proc. "Corrosion", San Francisco, CA, NACE, paper 54, 1987.

[9] P. Nelson and J. R. Stile, Met. Mater. 9 (1988) 559-564.

[10] R. E. Tatnall, A Practical Manual on Microbiologically Influenced Corrosion, Ed. G. Kobrin, NACE International, Houston, Tex., 1993, pp. 101-112.

[11] L. Garverick, Corrosion in the petrochemical industry, ASM International, Metals Park, 1994, p. 23.

[12] M. Ronald, Handbook of Microbiological Media, Ed. by Lawrence C. Parks, 1996, 746.

[13] M. Ruscak and T. P. Perng., J. Mater. Sci. Technol. 1 (1993) pp. 1-5.

[14] V. A. Alves, A. M., Chiorcea Paquim, A. Cavaleiro and C. M. A. Brett., Corros. Sci. 47 (2005) 2871-2882.

[15] H. An-Guo, L. Zhi-Yuan, Y. Sheng-Fu, Z. Long-Zao, Z. Guo-Dong, Trans China Weld Inst. 11 (2005) 123-126. 